\title{
British design pedagogies in Japanese design handbooks: \\ 2016 TAIPEI Focus on color education of the government school
of design in Britain
}

Yuko Takeuchi / Onomichi City University / Onomichi / Japan

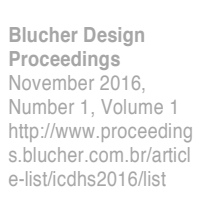

\begin{abstract}
The British influence on design education had been present in Japan since the 1870's. Modern Japanese art and design promoters introduced and translated a great deal of Western design theories into Japanese, including British treatises. Since then, important design handbooks about methodology were published. This trend reflected a growing concern about incorporating design as a part of compulsory education. Tracing the source back to its origin, the Government School of Design reformed design education in the early 1850s. The School of Design constructed the widespread practice of teaching industrial drawing as well as color education. Its compulsory art education was disseminated to other countries. Design methodologies including the teaching of color theory were also adopted by contemporary Japan. As a consequence, the Japanese government adopted the recommendation from the International Congress of Dessin Education held in 1900 in Paris that was based on the educational system of the Government School of Design.
\end{abstract}

\section{Keywords}

Color theory, 19th Century Britain, Cole Circle, compulsory art education

\section{Introduction}

The Government School of Design (renamed later as National Art Training School, now known as Royal College of Art) was founded in 1837 with the objective to improve the art of design. Here, the use of the word design was complex and meant "dessin" or "desegno". This beginning of a state-funded school had underlying in economic reasons. It aimed to refine the artistic quality of leading products in Britain. Along with this, it aimed to uplift public tastes in design through education. On the other hand, the school was planned to be differed from the Royal Academy of Arts. Since then, the school's branches gradually increased in local regions, but their results turned out to be ineffective to design reformers such as Henry Cole (1808-1882) and his group of companies. They endeavored to establish a more consistent educational system under the management of the Department of Practical Art, which was widely implemented throughout Britain as the "South Kensington system".

Previous studies have indicated the overseas influence of the Government School of Design in America, Australia, Canada, New Zealand, Brazil and India, but little comprehensive research has been made about their relationship with Japan. Moreover, they have contextualized the educational conflicts between art and design in their studies. What seems to be lacking is a consideration that the school's art system had developed to compulsory education. In addition, only a few studies show British influence on design methods which was called "benka" (conventional treatment) in Japanese education. However, it focused on 'drawing' only, and did not consider about 'color'. In fact, British design theorists and educators, Richard Redgrave (1804-88), Owen Jones (1809-74) and Christopher Dresser (1834-1904) wrote elaborate design treatises, and they had put importance on color theories in their books. Their teachings should have been reflected in the educational methods of the Government School of Design.

This study aims to show the relationships between British and Japanese design education by focusing on the formation of the modern educational system, and analyzing key design handbooks which were written by Japanese design educators. First, I will identify prominent theories of design practice in British design education. Secondly, I will describe how received British design theory was during the Meiji era. Finally, I list varied 
descriptions of design education, then examine teaching materials on color in the late nineteenth and early twentieth century Japan.

\section{The educational features of the government school of design}

After the establishment of the School of Design, the Council appointed the artist and scientist William Dyce (18061864) as a director. During his term from 1838 to1843, he introduced a practical teaching method of drawing and authored "the Drawing Book" that used geometrical outlines as a basis. Although the Schools of Design were criticized as "mere drawing schools", the textbook was highly influential in the following decade. Taking this opportunity for reform, Henry Cole, a British civil servant (who was the succeeding director) together with his circle endeavoured in reorganizing the Schools of Design using a centralized management system. The Art Superintendent Richard Redgrave took charge of forming the National Course of Instruction which consisted of four courses specifically drawing, painting, modelling and design, which had a total of twenty-three stages. He emphasized the importance of botany during the twenty-second stage of the curriculum, elementary design, gave the theme 'natural objects ornamentally treated and usually botanical' to students. The syllabus also included elementary drawing for public day schools which were implemented during the early stages that made children acquire skills in copying accurately in mechanical and imitative ways. Thus, the focus had always been the standards for industrial design, and it later transformed to public art education.

Furthermore, new methods of color instruction characterized its education. The application of color theory in Victorian Britain expanded from fine art to design, helping build the autonomy of design as a new genre. Also, color laws were useful in decoration and manufactures. The Cole circle fully realized the necessity of color education through the planning of the Great Exhibition of 1851. They adapted treatises on color harmony and contrast from the British chemist George Field (1777-1854) and the French chemist Michel Eugène Chevreul (17861889). In particular, Field's chief book Chromatography, published in 1835, helped establish the value of the three primary colors and of the harmonious color combinations in complementary contrast. His ideas were developed by Owen Jones and Richard Redgrave. According to them, harmonious color must contain 'equivalent amounts of the complements' (that is, 'chromatic equivalents'). Jones employed Field's theory as a basis for the color scheme of the Great Exhibition, which was set according to Field's prescribed proportions of eight parts blue, five red, and three yellow. With another reference to Jone's color theory, An Attempt to Define the Principles which Should Regulate the Employment of Colour in the Decorative Arts, Redgrave prepared a diagram to illustrate the harmonious relation of color for the schools and workshops of manufacturers and remarked about the laws of color,

To explain this I have prepared a diagram to show you that colours must be arranged together in specific and absolute quantities to be agreeable to the eye; it is founded on the experiments of Field, who laid down, from able researches and experiments, what these relative quantities must be. Thus, in arrangements of the primaries, a surface quantity of three yellow requires, to be agreeable to the eye, a surface of five red and eight blue; or three yellow harmonises with its secondary purple as three to thirteen in surface quantity. (Redgrave, Addresses of the Superintendents of the Department of Practical Art, Chapman and Hall, pp.78-79,1853.)

Then he wrote a textbook called, The Catechism of Colour in 1853, and illustrated Field's proportions of harmonious color and Chevreul's simultaneous contrast using a 'color cube' that he himself had developed. The designs of Kate Greenaway exemplified the reception of Redrave's teachings when she made them during stage twenty-two "elementary design" in the national course. This manual seems to be the first color textbook which was used in British public education. In this way, the educators incorporated the two main color theories into a new curriculum.

\section{The reception of British design education in the Meiji Era}

The Japanese government established a uniform national educational system called Gakusei system in 1872 . The Ministry of Education modelled this system after those in Western countries, including textbooks and curricula. A subject of art (gagaku or zuga) started to be taught in elementary and secondary education, which introduced traditional Western methods of drawing. However, it did not include color in the early stage. Separate from the subject of art education, the topic of the iro no zu (color chart) was introduced to primary school curricula around 1873, by providing questions and answers. This material was a direct copy of a contemporary American primary textbook by Marcius Willson (Ogata, 1987). The iro-zu consisted of two charts with accompanying color illustrations. Color chart no. 1 showed the seven spectral colors, their combinations, and their kindred colors. Interestingly, color chart no. 2 
clearly showed George Field's chromatic scale but did not discuss harmony among the colors in detail. The inclusion of color as a curriculum topic lasted only five or six years, not until 1904 was color education at the primary school level reintroduced in Japan.

Corresponding to the needs of higher art education, the Ministry of Education started up a board of inquiry of art education in 1885. As a result, the Governmental Art School (Tokyo School of Art) was founded in 1887. This school fulfilled the two functions: a general course (painting, sculpture and artistic crafts) as a part of professional training and a teacher's training course for secondary schools. The education policy followed a conservative approach for the Japanese traditional art representation. In accordance with the development of Japanese industry, the government required setting up technical colleges, and then established successively three governmental colleges which were equipped with the design course from 1897.

What needs to be noticed is the tendency of Japanese art educator to form design methodology which emerged just after the Paris Exposition of 1900. The government took part in it to raise national prestige through art. However, the exhibits were unpopular, because Japonism was becoming out of fashion among Western countries, whereas art-nouveau as a new style of art gained popularity. Therefore, the exposition gave an explicit watershed in Japanese design reform movement. Beyond that, the exposition also held the International Congress of "Dessin" Education, which proposed inclusion of design to compulsory art education. Furthermore, the congress emphasized the importance of color study to students. The Ministry of Education published this report and the sixth item on the agenda indicated the following:

Decorative design should include the following:

1. Geometrical study by means of linear application and division of surface

2. Sketching, especially plants from nature

3. The primary law of design and knowledge on the law of decoration

4. Inquiry about an undulation of objects in modelling and its decoration

5. Color study (A report on the International Congress of Dessin Education of 1900 in Paris,

The Ministry of Education, pp.93-96, 1902.)

As we have confirmed, all recommendations were common with the precedential teachings of

the Government School of Design. A government official Naohiko Masaki (in later, a director of Tokyo School of Art) joined this congress, and then set a board of inquiry of general art education. The said agenda made a great impact for officials to include design in primary and secondary education, since the Ministry of Education actually introduced 'surface decoration' as design (kôanga) in curriculum. In 1904, an official gazette, the 6,338 issue, announced to teach design to students from geometrical approach to sketching under the law of nature.

The announcement dealt with color education as significant learning, still the curriculum did not list it independently. Rather, it suggested teaching the names, the arrangement and the properties of color before practices with colored pencils (Kanpo, 8/15/1904). Through these processes, the board members focused on four educational issues; the training of art teachers, the objectives and curriculum of general art education and the equipment of class room including teaching aids. Significantly, the members had great interest that the British government had added art into compulsory education in 1860, specifically after the Great Exhibition of 1851. They considered that Japan should learn lessons from Britain's educational system with the failure of the Paris Exposition of 1900 as the turning point. Thus, the Schools of Design was regarded as an ideal model in order to improve technical education as art.

\section{The introduction of color theory in design handbooks}

The Ministry of Education and other Metropolitan authorities successively held lectures to teach design to art teachers handling general courses. Consequently, this circumstance guided the lecturers in publishing the following design handbooks: Shinzo Komuro's Lectures of Design Method (Zuanhô Kogi) in 1907 and General Design Methods (Ippan Zuanhô) in 1909, Shimada Yoshinari's Lectures on Industrial Design Method (Kogei Zuanhô Kogi) in1909, Kou Morita's The Method of Decorative Design (Soshoku Zuanhô) in 1910, and Kannosuke Hara's A New Edition of Design Method (Shinpen Zuanhô) in 1911. These handbooks played important roles not only for art teachers but for specialists to invent new decorations from motifs according to the procedures described by these authors. They also had common contents about composition, form, color of decorative design and their application in design.

The pioneer design specialist and educator was Shinzo Komuro (1870-1922). He was an associate professor of industrial design in Tokyo Technical School (now known as Tokyo Institute of Technology) which was founded by the government. Columbine (odamaki) illustrated his introduction of the Government School of 
Design's conventional treatment. A precedent for similar example was Miyamoto Sanpei's Drawing book for Elementary School (Shôgaku Hutsu Gagakubon), which had been published by Ministry of Education in 1878. Unlike Miyamoto, Komuro explained how pictorial sketch from natural observation transformed into new design. More importantly, his methodology came from Christopher Dresser according to General Design Methods (Komuro, p.160.). Moreover, Kyoto Higher Technical School (now known as Kyoto Institute of Technology) also adopted this method in the curriculum. Consequently, Benka had considerable influence on the new comprehensive national art textbook for elementary grades entitled New Textbooks of Drawing (Shintei gachô) published in 1910.

Furthermore, Komuro introduced the methods of color arrangement for design for the first time in Lectures of Design Method. He explained about primary, secondary, tertiary colors, the psychological effects of colors, contrast, harmony and the color wheel. This became the firm basis for color instruction in the subsequent handbooks on design. Since then, Shimada introduced Field's theory of chromatic equivalents and Chevreul's simultaneous contrast in his book Lectures on Industrial Design Method through illustrations. Instead, Morita only dealt with contrast, harmony, complementary colors, pigments and coloring techniques in The Method of Decorative Design. Hara also gave the same description for the most part, but provided a thorough list of references on British design theory in A New Edition of Design Method. New Textbooks of Drawing organized the content systematically such as drawing, painting, composition, colour theory, decoration and design, and inserted color wheel of twelve hues that was derived from three primary colors.

In the same way, most contemporary educators omitted the scientific and philosophical ideas in which the original sources had been rooted. We have confirmed that these attitudes were identical with those of Victorian design reformers. Color theories had been taught depending on form or drawing. In their perspective, the procedure of making design meant that the form comes first, and then the color follows a subordinate position. Thus color education was restricted to use the basic color properties and its arrangement for practical applications.

\section{Conclusion}

The Government School of Design provided the comprehensive curriculum in art and design with the National Course of Instruction. An important point to emphasize is the Cole Circle incorporated color studies into the curriculum as opposed to the Academies of Art which put emphasis on drawing in the early years. A synthesis of form and color should be essential for their education.

In particular, the British design educators paid great attention to George Field's color theory of primaries, as well as French chemist Chevreul's color theory. Redgrave made the color diagram for visual aids and published the textbook, An Elementary Manual of Colour, in 1853. In short, the educators mainly introduced the two theories into the curriculum. This textbook dealt with color properties, harmony and contrast that were integral parts of producing decorative design. It became one of the earlier exemplars for instruction on color.

Under the waves of modernization, the Japanese educators consulted the British design theories, and used them comparatively in their books. Through the Japanese design reform since 1900, the inclusion of design to compulsory art education started. Meanwhile, benka became the influential design method, while color theories in design handbooks became the partial introduction of Western color theories. Their descriptions did not cover how to complement color application for students. It might be difficult to measure the whole impact of British design and color theories in the early art educational stages in Japan. Still, color that is, in Field's colour theory had been adopted once at first, and form or design methodology was accepted later. This showed a unique relationship between Britain and Japan in the field of art and design education.

\section{References}

Field, G. (1817) Chromatics; or, the analogy, harmony, and philosophy of colours, London: A.J.Valpy. Mrs.Merrifield (1851/1970) "The Harmony of colours", The Crystal Palace Exhibition, Dover Pub.

Jones, O. (1852) An attempt to define the principles which should regulate the employment of colour in the decorative arts, London: G. Barclay.

Redgrave, R. (1853) An elementary manual of colour, with a Catechism: to be used with the diagram illustrating the harmonious relations of colour, London: Chapman \& Hall.

Cole, $\mathrm{H}$ and Redgrave, R. (1853), Addresses of the Superintendents of the Department of Practical Art, London: Chapman and Hall. 
A Report on the International Congress of Dessin Education of 1900 in Paris (1902), The Ministry of Education, pp.93-96.

An Official Gazette Kanpo(1904), the 6,338 issue.

Komuro, S. (1906), Zuanhô Kogi, Tokyo: Gengendo Shobo.

Komuro, S. (1909), Ippan Zuanhô, Tokyo: Maruzen.

Shimada, Y. (1909), Kogei Zuanhô Kogi, Tokyo: Kôbun Sha.

Morita, K. (1910), Soshoku Zuanhô, Tokyo: Kenchiku Shoin.

Hara, K. (1911), Shinpen Zuanhô, Tokyo: Seibi Dô.

Ogata, K. (1980), "Meiji to Design: Komuro Shinzo (1)", Journal of the Japan Society of Design, vol. 19, pp.2-25.

Ogata, K. (1987), "Color education in elementary schools in the meiji era", The Journal of Color Science Association of Japan, vol. 11(2), pp.101-112.

Kaneko, K. (1992), Kindai Nihon Bijutsu Kyoiku no Kenkyu:Meiji Jidai, Tokyo: Chuo Kôron Bijutsu Shuppan. Hino, E. (1994), "Design Technical Books in Meiji Era”, Bulletin of Japanese Society for the Science of Design, Vol.41(3), pp23-30.

\section{Biographical note}

Yuko Takeuchi is a part-time lecturer at Onomichi City University in Japan. She is working on a research on color theory during the 19th century in Britain. She completed her PhD dissertation entitled, 'A study of

Christopher Dresser: the Formation and Development of His Design Principles' at Osaka University in 2009. 